\title{
Evaluation of the acute toxicity of the extracts of Anacyclus pyrethrum var. pyrethrum (L.) and Anacyclus pyrethrum var. depressus Maire in Swiss mice
}

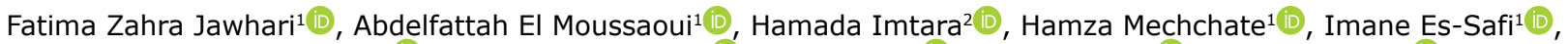

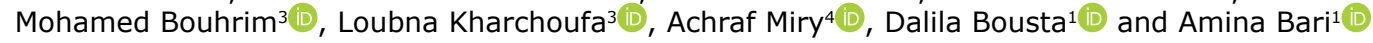

1. Laboratory of Biotechnology, Environment, Agri-Food, and Health LBEAS, Faculty of Sciences, University Sidi Mohamed Ben Abdellah USMBA Fez, Morocco; 2. Faculty of Arts and Sciences, Arab American University Palestine, P. O. Box 240, Jenin, Palestine; 3. Laboratory of Bioresources, Biotechnology, Ethnopharmacology and Health, Faculty of Sciences, Mohammed First University, Oujda, Morocco; 4. Laboratory of University Hospital Mohammed 6 Oujda, Morocco.

Corresponding author: Hamada Imtara, e-mail: hamada.tarayrah@gmail.com Co-authors: FZJ: jawhari.fatimazahra@gmail.com, AE: Abdelfattah.elmoussaoui@usmba.ac.ma,

HM: hamza.mechchate@usmba.ac.ma, IE: imane.essafi1@usmba.ac.ma, MB: mohamed.bouhrim@gmail.com, LK: khloubna43@gmail.com, AM: achrafmiry@outlook.com,DB: dalila.bousta@usmba.ac.ma,

AB: amina.bari@usmba.ac.ma

Received: 23-09-2020, Accepted: 07-01-2021, Published online: 22-02-2021

doi: www.doi.org/10.14202/vetworld.2021.457-467 How to cite this article: Jawhari FZ, El Moussaoui $A$, Imtara $H$, Mechchate H, Es-Safi I, Bouhrim M, Kharchoufa L, Miry A, Bousta D, Bari A (2021) Evaluation of the acute toxicity of the extracts of Anacyclus pyrethrum var. pyrethrum (L.) and Anacyclus pyrethrum var. depressus Maire in Swiss mice, Veterinary World, 14(2):457-467.

\begin{abstract}
Background and Aim: Anacyclus pyrethrum (L.) has been used in traditional North African and Indian medicine for the treatment of several diseases such as cancer, rheumatism, epilepsy, diabetes, and Alzheimer's disease. Despite its medical benefits, few studies have examined its toxicity. The present study evaluated the acute toxicity of hydroethanolic extracts of different parts (roots, seeds, leaves, and capitula) of two varieties of $A$. pyrethrum (L.), namely, A. pyrethrum var. pyrethrum (L) and A. pyrethrum var. depressus (Ball) Maire, in mice.
\end{abstract}

Materials and Methods: Acute toxicity was evaluated after the oral administration of different extracts at doses of 300 , 500 , and $2000 \mathrm{mg} / \mathrm{kg}$. Mortality, body weight, general behavior, and adverse effects were observed daily for 14 days. At the end of the experiment, mice were sacrificed, and biochemical parameters and histopathology of the liver, kidneys, and spleen were analyzed.

Results: The extracts of different parts of both plants induced no signs of toxicity or mortality during the observation period, excluding capitulum and seed extracts, which induced slight sedation at a dose of $2000 \mathrm{mg} / \mathrm{kg}$. The LD $\mathrm{LD}_{50}$ of the extracts was estimated to exceed $2000 \mathrm{mg} / \mathrm{kg}$. The administration of $A$. pyrethrum var. pyrethrum roots at a dose of $300 \mathrm{mg} / \mathrm{kg}$ resulted in significantly increased AST levels. However, the A. pyrethrum var. depressus root extract induced significant increases in the levels of both transaminases (alanine aminotransferase [ALT] and aspartate aminotransferase [AST]). The remaining extracts of both plants at a dose of $500 \mathrm{mg} / \mathrm{kg}$ significantly increased AST levels. Moreover, all plant extracts excluding the $A$. pyrethrum var. pyrethrum capitulum extract at $2000 \mathrm{mg} / \mathrm{kg}$ provoked significant increases in AST levels, and $A$. pyrethrum var. depressus roots provoked a significant increase of ALT levels. Meanwhile, mice treated with high doses of extracts $(2000 \mathrm{mg} / \mathrm{kg})$ displayed histopathological changes in the liver, kidneys, and spleen characterized by hepatic distress, inflammatory infiltration, focal tubular necrosis, vascular congestion, and lymphoid hyperplasia.

Conclusion: The results of the present study indicate that the hydroethanolic extracts of different parts of two varieties of A. pyrethrum (L.) were not toxic in mice at low concentrations, whereas some toxic effects were detected in mice treated at $2000 \mathrm{mg} / \mathrm{kg}$.

Keywords: acute oral toxicity, Anacyclus pyrethrum var. depressus (Ball) Maire, Anacyclus pyrethrum var. pyrethrum (L), histopathology, serum biochemistry analysis.

\section{Introduction}

The use of medicinal plants, whether as pure compounds, extracts, or derivatives, is a real treasure for humanity because they produce a wide range of drugs for treating various illnesses. Anacyclus pyrethrum

Copyright: Jawhari, et al. Open Access. This article is distributed under the terms of the Creative Commons Attribution 4.0 International License (http://creativecommons.org/licenses/ by/4.0/), which permits unrestricted use, distribution, and reproduction in any medium, provided you give appropriate credit to the original author(s) and the source, provide a link to the Creative Commons license, and indicate if changes were made. The Creative Commons Public Domain Dedication waiver (http:// creativecommons.org/publicdomain/zero/1.0/) applies to the data made available in this article, unless otherwise stated.
(L.) is a plant that belongs to the Asteraceae family and genus Anacyclus [1]. It is commonly known as pellitory, Aqar Qarha, Oud El Attas, African pyrethrum, and Akarkara. It is endemic to Morocco, Algeria, and Spain, and it has been introduced in India, Australia, France, Germany, Nepal, Pakistan, Poland, and Ukraine. In traditional medicine, the roots of this plant are recommended as a sialagogue for treating several diseases and ailments. They are used in the form of a mouthwash to treat toothache and problems related to saliva secretion, and they are used as a gargle to treat angina, digestion problems, paralysis of the tongue, and lethargy. Moreover, the decoction of the roots is 
also used to treat paralysis of the limbs, and the roots can also be used in the form of cream based on animal fats to treat gout and sciatica [2,3]. Other pharmacological and biological properties have been reported in the literature, such as antibacterial and antifungal activities [4-6], aphrodisiac properties [7-9], effects against gout and sciatica [10], immunostimulant properties [11-14], anti-convulsive activity [7,15,16], antidiabetic effects [17,18], anti-parasitic and antibiotic activities [19], insecticidal properties [20], antioxidant effects [14,21], anti-inflammatory properties [22], local anesthetic effects [23], anti-epileptic properties [15,24], memory-enhancing effects [25], anti-rheumatic activity [20], and wound-healing properties [26]. These properties are the results of the phytochemical constituents of the plant, such as phenolic compounds, flavonoids, alkaloids, and tannins [22].

In recent decades, much research has been conducted on the therapeutic properties of many medicinal plants, but there is little information concerning their toxic or harmful effects [27]. In addition, no study has described the toxicity profile or side effects of different parts of A. pyrethrum (L.). In Morocco, two varieties of $A$. pyrethrum (L.) have been identified: A. pyrethrum var. pyrethrum (L.) and A. pyrethrum var. depressus (Ball) Maire [28,29].

Thus, the present study was conducted to evaluate the acute toxicity of different extracts (roots, seeds, leaves, and capitula) of A pyrethrum var. pyrethrum (L.) and A. pyrethrum var. depressus (Ball) Maire in Swiss albino mice.

\section{Materials and Methods}

\section{Ethical approval}

The ethical institutional committee, Faculty of Sciences Dhar El Mahraz, University Sidi Mohamed Ben Abdallah, Fez, Morocco, approved the protocol. All the experimental proceedings achieved in laboratory animals followed the internationally accepted standard guidelines for animal care. The authors tried to minimize animal suffering and the number of animals used.

\section{Study period and location}

This study was conducted in Septembre 2019 at Sidi Mohamed Ben Abdellah University, Morocco.

\section{Collection and extraction of plant material}

The two varieties of $A$. pyrethrum (L.) were collected in July 2019 from the Timahdite region in the Middle Atlas, Morocco. Then, the plants were identified and authenticated by Professor Bari Amina, a botanist in the Department of Biology, Laboratory of Biotechnology, Environment, Agri-Food, and Health, Faculty of Sciences, University Sidi Mohamed Ben Abdellah (USMBA) Fez, Morocco. These specimens have been deposed in the herbarium under the voucher numbers A31/31-5-18/TM and A32/31-5-18/TM.

\section{Preparation of plant extracts}

Different parts of both plants were washed with tap water, separated, and dried in the shade for 1 week at room temperature. Then, the parts were crushed and reduced to a coarse powder. Then, $10 \mathrm{~g}$ of each powder were cold-macerated with ethanol $(70 \%)$ for $48 \mathrm{~h}$, the extracts obtained were filtered and concentrated under reduced pressure at $40^{\circ} \mathrm{C}$, and the obtained residues were stored at $4^{\circ} \mathrm{C}$ until use [30].

\section{Experimental animals}

One hundred twenty-five male Swiss mice $(30 \pm 2 \mathrm{~g})$ were used. The animals were housed in Makrolon cages under standard laboratory conditions (12 h light $/ 12 \mathrm{~h}$ darkness, $21 \pm 2^{\circ} \mathrm{C}$, relative humidity $=55 \pm 5 \%$ ). The animals were given a standard pellet diet and water ad libitum throughout the experimental period.

\section{Acute toxicity study}

The acute toxicity study was conducted following OECD guideline No. 425 (OECD, 2008). The animals were randomly divided into 25 groups (five mice per group). The treated animals received the plant extracts at a dose of 300,500 , or $2000 \mathrm{mg} / \mathrm{kg}$, and the control group received distilled water $(10 \mathrm{ml} / \mathrm{kg})$. After a single dose of each plant extract was administered, the animals were followed for $4 \mathrm{~h}$ each day for 14 days to note changes in behavior and signs of toxicity (digestion, body weight, food intake, urination, skin changes, sedation, diarrhea, and death). At the end of the experiment ( 2 weeks), the animals were subjected to light diethyl ether anesthesia, and blood was obtained through cardiac puncture. Next, the animals were sacrificed. Then, plasma was separated by centrifugation at $3000 \mathrm{rpm}$ at $4^{\circ} \mathrm{C}$ for $20 \mathrm{~min}$ to assess biochemical parameters, and organ tissue (liver, kidneys, and spleen) was conserved to conduct histological examinations.

The relative organ weight (ROW) was calculated according to the following formula [31]:

$\mathrm{O}_{\mathrm{w}}$ : organ weight

$\mathrm{B}_{\mathrm{w}}^{\mathrm{w}}$ : body weight.

\section{Biochemical parameters}

The biochemical parameters were measured in plasma. Urea levels were determined using the enzymatic method [32], creatinine levels were measured using the Jaffe method [33], and ALT and AST levels were measured using the IFCC method without pyridoxal-5-phosphate [34]. All tests were performed with the Architect c8000 automated analyzer using commercial reagent kits.

\section{Histological analysis}

The organ tissues of the animals used in this study were prepared for the examination of microscopic lesions. A $10 \%$ buffered formalin solution was used to secure the organs within $48 \mathrm{~h}$, and the organs were embedded in paraffin. The samples were cut to a thickness of approximately 4-5 $\mu \mathrm{m}$ from tissue sections using a rotating microtome, and the mounted glass blades were kept on a heating plate $\left(54^{\circ} \mathrm{C}\right)$ overnight [35]. Finally, the protocol for hematoxylin and eosin staining was used. 


\section{Statistical analysis}

The analysis was performed using Graph Prism version 7 software (San Diego, California, USA), statistical processing was performed through analysis of variance, and comparisons of means were made using the Tukey test. The data were expressed as the mean \pm SEM.

\section{Results}

\section{Behavioral parameter assessment}

During the experiment, no mortalities were recorded. However, the mice treated with capitulum and seed extracts of both plants (APPC, APPG, APDC, and APDG) at a dose of $2000 \mathrm{mg} / \mathrm{kg}$ displayed slight signs of sedation during the first $4 \mathrm{~h}$ after oral administration (Table-1). Therefore, the $\mathrm{LD}_{50}$ of the different extracts both varieties studied exceeded $2000 \mathrm{mg} / \mathrm{kg}$.

\section{Body weight}

According to Figure-1, the different plant extracts did not induce any abnormal changes in the body weight of the mice. Moreover, there was no significant difference in the changes of body weight between the control group and the treatment groups, which proves the absence of toxicity.

\section{ROW}

The results of the effect of the plant extracts on organ weight are presented in Table-2. There was no significant difference in ROW or the general appearance of organs (liver, spleen, and kidneys) between the treatment groups and the control group.

\section{Biochemical parameters}

The effect of the plant extracts on AST, ALT, creatinine, and urea levels is presented in Table-3. The root extracts of both plants (APPR and APDR) at a dose of $300 \mathrm{mg} / \mathrm{kg}$ significantly increased AST levels, but no significant changes in ALT, urea, and creatinine levels were noted. A dose of $500 \mathrm{mg} / \mathrm{kg}$ induced a significant increase in AST level for the root, seed, and capitulum extracts of both plants, and no significant change was observed in the other biochemical parameters. However, a dose of $2000 \mathrm{mg} / \mathrm{kg}$ provoked a significant increase in AST levels for all plant extracts excluding the capitulum extract of $A$. pyrethrum var. pyrethrum plant (APPC). Moreover, at the same dose, the root extract of $A$. pyrethrum var.
(APDR) provoked a significant increase in ALT levels in comparison with the control group levels, whereas no significant changes were observed for the other biochemical parameters.

\section{Histopathological analysis}

The results of the histological examination for the liver, spleen, and kidneys in the treatment and control groups are presented in Figures-2-4, respectively. Microscopic examination of all tissue sections collected (liver, spleen, and kidneys) from mice administered extracts of both plants at a dose of $300 \mathrm{mg} / \mathrm{kg}$ exhibited a normal architecture and no abnormalities, alterations, or degenerative or infiltrative lesions (Table-4). The leaf extracts (APPF and APDF) of both plants at a dose of $500 \mathrm{mg} / \mathrm{kg}$ induced hepatocyte damage, whereas sinusoid dilatation was observed in the mice treated with the capitulum extract of A. pyrethrum var. pyrethrum (APPC). However, no abnormalities were noted in the spleen and kidneys. Meanwhile, the doses of 500 and $2000 \mathrm{mg} / \mathrm{kg}$ induced hepatocyte damage in mice treated with the leaf and seed extracts of both plants (ADPF, APPF, APDG, and APPG), whereas sinusoid dilatation observed in the livers of mice treated with A. pyrethrum var. pyrethrum (APPC). Inflammatory infiltration of the portal and lobal spaces was observed in the livers of mice treated with the roots extract of $A$. pyrethrum var. depressus (APDR). Moreover, focal tubular necrosis was observed in the kidneys of mice treated with the roots, seeds, leaves, and capitula of A. pyrethrum var. pyrethrum. However, vascular congestion and lymphoid hyperplasia were observed in the spleens of mice treated with A. pyrethrum var. pyrethrum extracts excluding the root extract (APPC).

\section{Discussion}

The toxicity of a plant is defined as the potential of its extracts to cause harm to humans or animals. These effects can include harm to cells, organs, or the whole body. The symptoms caused by the toxic effects of plants are dominated by the following areas: Brain (e.g., convulsions, paralysis, depression, anorexia, shivers, dizziness, and coma), gastrointestinal tract (nausea, vomiting, and diarrhea), kidneys (acute renal failure, urination, and necrosis), and

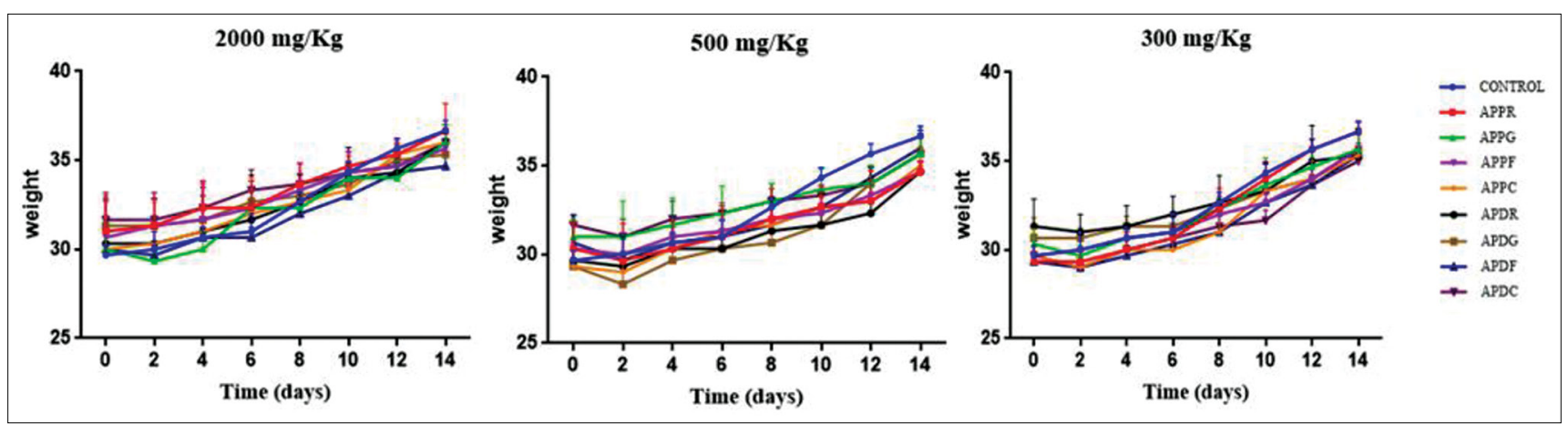

Figure-1: Body weight of mice in the treated and control groups during the 14-day acute toxicity assessment. 


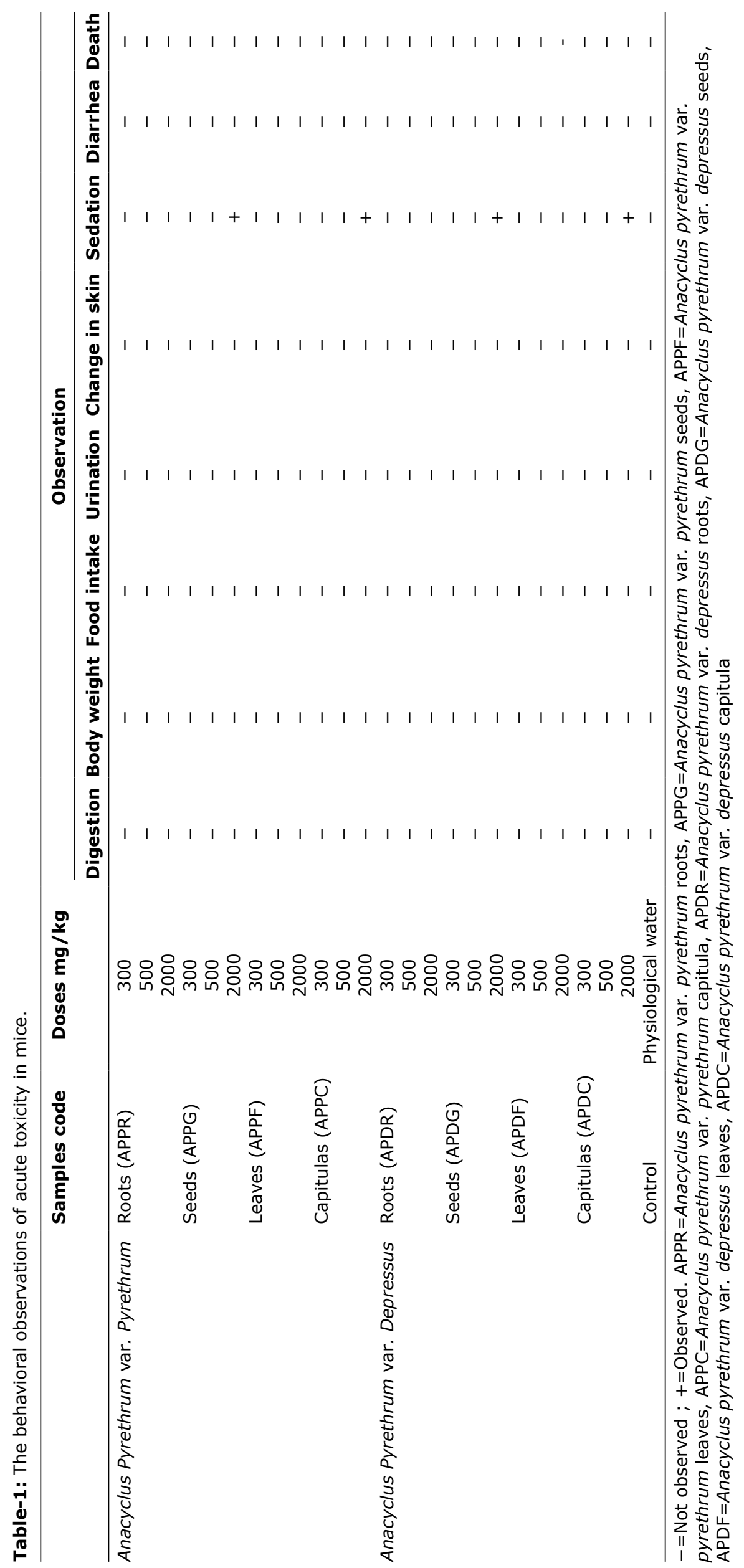


Table-2: Relative organ weights of mice, 14 days after acute oral administration of extracts from different parts of the two varieties Anacyclus pyrethrum var. pyrethrum (L) and Anacyclus pyrethrum var. depressus (Ball) Maire.

\begin{tabular}{|c|c|c|c|c|c|}
\hline & \multirow[t]{2}{*}{ Samples code } & \multirow[t]{2}{*}{ Doses mg/kg } & \multicolumn{3}{|c|}{ Relative organ weights } \\
\hline & & & liver & kidneys & spleen \\
\hline \multirow[t]{12}{*}{ Anacyclus Pyrethrum var. Pyrethrum } & Roots (APPR) & 300 & $6.53 \pm 0.46$ & $1.30 \pm 0.14$ & $0.86 \pm 0.04$ \\
\hline & & 500 & $7.16 \pm 0.31$ & $1.25 \pm 0.11$ & $0.91 \pm 0.06$ \\
\hline & & 2000 & $6.36 \pm 0.63$ & $1.25 \pm 0.08$ & $0.58 \pm 0.05$ \\
\hline & Seeds (APPG) & 300 & $6.25 \pm 0.50$ & $1.30 \pm 0.05$ & $0.77 \pm 0.1$ \\
\hline & & 500 & $6.78 \pm 0.02$ & $1.25 \pm 0.11$ & $0.69 \pm 0.39$ \\
\hline & & 2000 & $5.5 \pm 1.34$ & $1.02 \pm 0.15$ & $0.81 \pm 0.14$ \\
\hline & Leaves (APPF) & 300 & $6.56 \pm 0.19$ & $1.27 \pm 0.09$ & $0.81 \pm 0.03$ \\
\hline & & 500 & $6.63 \pm 0.49$ & $1.36 \pm 0.11$ & $0.80 \pm 0.08$ \\
\hline & & 2000 & $5.80 \pm 0.09$ & $1.49 \pm 0.21$ & $0.67 \pm 0.10$ \\
\hline & Capitulas (APPC) & 300 & $6.72 \pm 0.6$ & $1.36 \pm 0.07$ & $0.79 \pm 0.14$ \\
\hline & & 500 & $6.39 \pm 0.33$ & $1.33 \pm 0.13$ & $0.73 \pm 0.23$ \\
\hline & & 2000 & $5.28 \pm 0.64$ & $1.27 \pm 0.22$ & $0.69 \pm 0.09$ \\
\hline \multirow[t]{13}{*}{ Anacyclus Pyrethrum var. Depressus } & Roots (APDR) & 300 & $7.15 \pm 0.03$ & $1.32 \pm 0.07$ & $0.81 \pm 0.01$ \\
\hline & & 500 & $6.60 \pm 0.28$ & $1.32 \pm 0.05$ & $0.84 \pm 0.01$ \\
\hline & & 2000 & $7.85 \pm 0.28$ & $1.42 \pm 0.11$ & $0.95 \pm 0.2$ \\
\hline & & 300 & $6.51 \pm 0.67$ & $1.24 \pm 0.03$ & $0.78 \pm 0.06$ \\
\hline & Seeds (APDG) & 500 & $6.5 \pm 0.14$ & $1.37 \pm 0.11$ & $0.76 \pm 0.02$ \\
\hline & & 2000 & $6.41 \pm 0.59$ & $1.16 \pm 0.08$ & $1.11 \pm 0.39$ \\
\hline & Leaves (APDF) & 300 & $6.19 \pm 0.05$ & $1.29 \pm 0.07$ & $0.78 \pm 0.04$ \\
\hline & & 500 & $7.09 \pm 0.94$ & $1.24 \pm 0.08$ & $0.70 \pm 0.06$ \\
\hline & & 2000 & $7.05 \pm 0.56$ & $1.25 \pm 0.06$ & 1.260 .18 \\
\hline & Capitulas (APDC) & 300 & $6.76 \pm 0.28$ & $1.31 \pm 0.06$ & $0.82 \pm 0.14$ \\
\hline & & 500 & $6.35 \pm 1.06$ & $1.35 \pm 0.11$ & $0.75 \pm 0.14$ \\
\hline & & 2000 & $7.33 \pm 0.16$ & $1.59 \pm 0.15$ & $0.71 \pm 0.02$ \\
\hline & Control & physiological & $6.34 \pm 0.31$ & $1.31 \pm 0.13$ & $0.79 \pm 0.13$ \\
\hline
\end{tabular}

Table-3: Biochemical parameters of mice serum after acute oral administration of extracts of the different parts of the two varieties studied.

\begin{tabular}{|c|c|c|c|c|c|c|}
\hline & \multirow[t]{2}{*}{ Simples code } & \multirow[t]{2}{*}{ Doses mg/kg } & \multicolumn{4}{|c|}{ Biochemical parameters } \\
\hline & & & AST & ALT & Urea & Creatinine \\
\hline Anacyclus Pyrethrum & Roots (APPR) & 300 & $250 \pm 6.65 * * *$ & $30.33 \pm 1.33$ & $0.28 \pm 0.007$ & $4.23 \pm 0.14$ \\
\hline \multirow{11}{*}{ var. Pyrethrum } & & 500 & $261 \pm 4.05 * *$ & $31 \pm 2.02$ & $0.38 \pm 0.012$ & $4 \pm 0.208$ \\
\hline & & 2000 & $315 \pm 14 * *$ & $54 \pm 4.04$ & $0.37 \pm 0.02$ & $4.5 \pm 0.28$ \\
\hline & Seeds (APPG) & 300 & $285.66 \pm 8.17$ & $32 \pm 2.9$ & $0.37 \pm 0.01$ & $3.5 \pm 0.28$ \\
\hline & & 500 & $257.7 \pm 4.05^{* *}$ & $40.35 \pm 3.52$ & $0.3 \pm 0.03$ & $3.56 \pm 0.29$ \\
\hline & & 2000 & $210 \pm 9.07 * * *$ & $50.7 \pm 1.85$ & $0.40 \pm 0.06$ & $4.23 \pm 0.62$ \\
\hline & Leaves (APPF) & 300 & $277 \pm 4.93$ & $36.6 \pm 4.09$ & $0.29 \pm 0.04$ & $3.93 \pm 0.43$ \\
\hline & & 500 & $275 \pm 4.63$ & $30 \pm 0.57$ & $0.35 \pm 0.01$ & $3.46 \pm 0.08$ \\
\hline & & 2000 & $232 \pm 5.92 * * *$ & $39 \pm 3.17$ & $0.40 \pm 0.04$ & $3.54 \pm 0.29$ \\
\hline & Capitulas (APPC) & 300 & $286.33 \pm 8.08$ & $42.53 \pm 2.02$ & $0.38 \pm 0.01$ & $3.73 \pm 0.17$ \\
\hline & & 500 & $258.7 \pm 3.28 * *$ & $36 \pm 1.52$ & $0.31 \pm 0.03$ & $3.63 \pm 0.27$ \\
\hline & & 2000 & $296 \pm 6.48$ & $32 \pm 6.11$ & $0.32 \pm 0.01$ & $3.5 \pm 0.28$ \\
\hline Anacyclus Pyrethrum & Roots (APDR) & 300 & $255 \pm 5.78^{* *}$ & $31.55 \pm 3.71$ & $0.28 \pm 0.17$ & $4 \pm 0.57$ \\
\hline \multirow{12}{*}{ var. Depressus } & & 500 & $254.3 \pm 3.52 * *$ & $32 \pm 2.08$ & $0.42 \pm 0.01$ & $3.43 \pm 0.14$ \\
\hline & & 2000 & $326 \pm 15.37 * * *$ & $63 \pm 7.21 *$ & $0.48 \pm 0.05$ & $4.23 \pm 0.39$ \\
\hline & Seeds (APDG) & 300 & $285 \pm 9.84$ & $41.66 \pm 1.76$ & $0.31 \pm 0.01$ & $4.06 \pm 0.12$ \\
\hline & & 500 & $258 \pm 2.64 * *$ & $33.8 \pm 2.4$ & $0.28 \pm 0.03$ & $4 \pm 0.12$ \\
\hline & & 2000 & $234 \pm 12.41 * * *$ & $26.4 \pm 3,71$ & $0.44 \pm 0.02$ & $3.4 \pm 0.33$ \\
\hline & Leaves (APDF) & 300 & $281.3 \pm 8.76$ & $30.33 \pm 3.52$ & $0.30 \pm 0.03$ & $4.33 \pm 0.33$ \\
\hline & & 500 & $272 \pm 4.37$ & $31 \pm 0,88$ & $0.31 \pm 0.02$ & $3.36 \pm 0.20$ \\
\hline & & 2000 & $254.7 \pm 10.89 *$ & $50.6 \pm 8.29$ & $0.42 \pm 0.04$ & $3.96 \pm 0.54$ \\
\hline & Capitulas (APDC) & 300 & $275.23 \pm 13.1$ & $35 \pm 2.02$ & $0.41 \pm 0.009$ & $3 \pm 0.23$ \\
\hline & & 500 & $260 \pm 4.80 * *$ & $35.37 \pm 5.04$ & $0.29 \pm 0.017$ & $3.53 \pm 0.29$ \\
\hline & & 2000 & $235 \pm 11.71 * * *$ & $48 \pm 6.55$ & $0.52 \pm 0.08$ & $5 \pm 0.57$ \\
\hline & Control & $\begin{array}{l}\text { Physiological } \\
\text { water }\end{array}$ & $278 \pm 4.35$ & $39 \pm 1.73$ & $0.30 \pm 0.01$ & $3.6 \pm 0.32$ \\
\hline
\end{tabular}

\footnotetext{
Values are expressed mean \pm SEM. AST=Aspartate aminotransferase, ALT=Alanine aminotransferase. ${ }^{*}$ Correlation is significant at the level $P<0.05$. **Correlation is significant at the level $P<0.01 * * *$. Correlation is significant at the level $P<0.001$. Values are expressed mean \pm SEM. APPR $=$ Anacyclus pyrethrum var. pyrethrum roots, APPG $=$ Anacyclus pyrethrum var. pyrethrum seeds, $\mathrm{APPF}=$ Anacyclus pyrethrum var. pyrethrum leaves, APPC =Anacyclus pyrethrum var. pyrethrum capitula, APDR=Anacyclus pyrethrum var. depressus roots, APDG=Anacyclus pyrethrum var. depressus seeds, APDF=Anacyclus pyrethrum var. depressus leaves, APDC=Anacyclus pyrethrum var. depressus capitula
} 


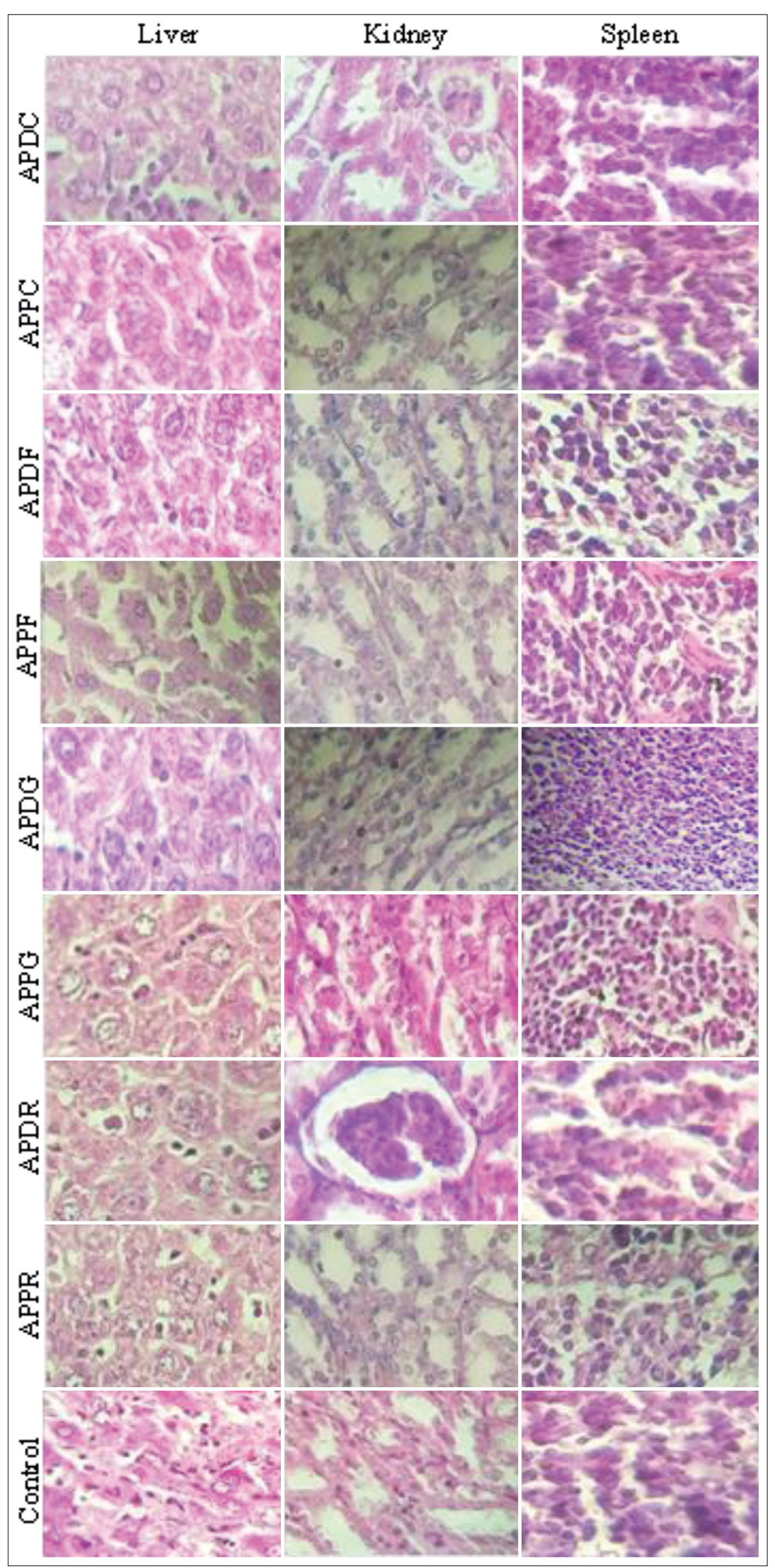

Figure-2: Histopathological observation of mice organs (liver, kidney, and spleen) from the control and the groups treated with $300 \mathrm{mg} / \mathrm{Kg}$ of the extracts from the different parts of the two varieties Anacyclus pyrethrum var. pyrethrum (L) and Anacycluspyrethrum var. depressus (Ball) Maire.

liver (liver dysfunction and cell destruction, necrosis, and lobar hepatitis) [36]. The results of this study demonstrated that the intake of these plant extracts did not induce the appearance of toxic symptoms, 


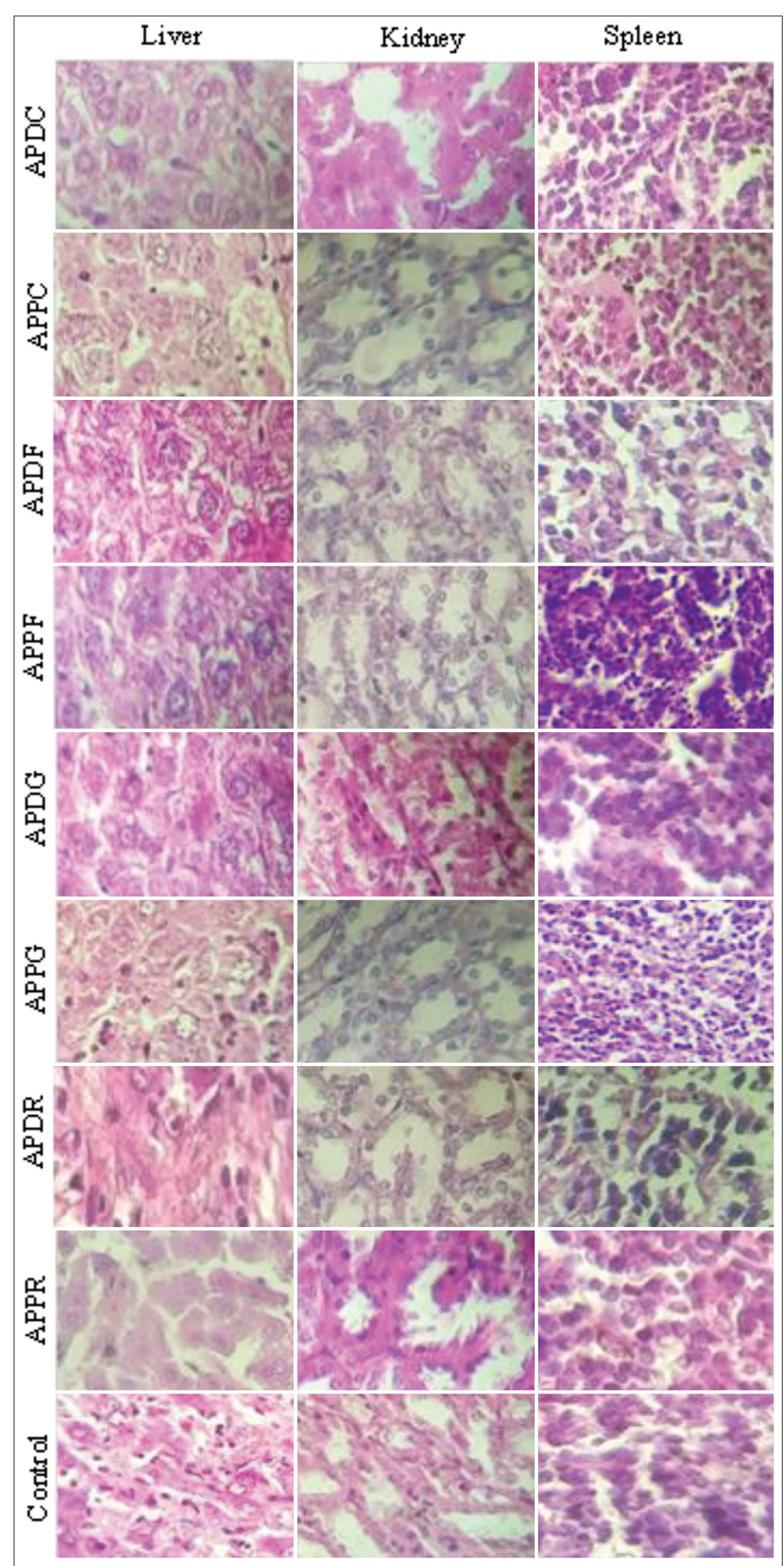

Figure-3: Histopathological observation of mice organs (liver, kidney, and spleen) from the control and the groups treated with $500 \mathrm{mg} / \mathrm{Kg}$ of the extracts from the different parts of the two varieties Anacyclus pyrethrum var. pyrethrum (L) and Anacyclus pyrethrum var. depressus (Ball) Maire.

excluding the capitulum and seed extracts of both species at a dose of $2000 \mathrm{mg} / \mathrm{kg}$. At this dose, mice exhibit mild signs of sedation during the first $4 \mathrm{~h}$ after oral administration of the extracts, and this symptom 


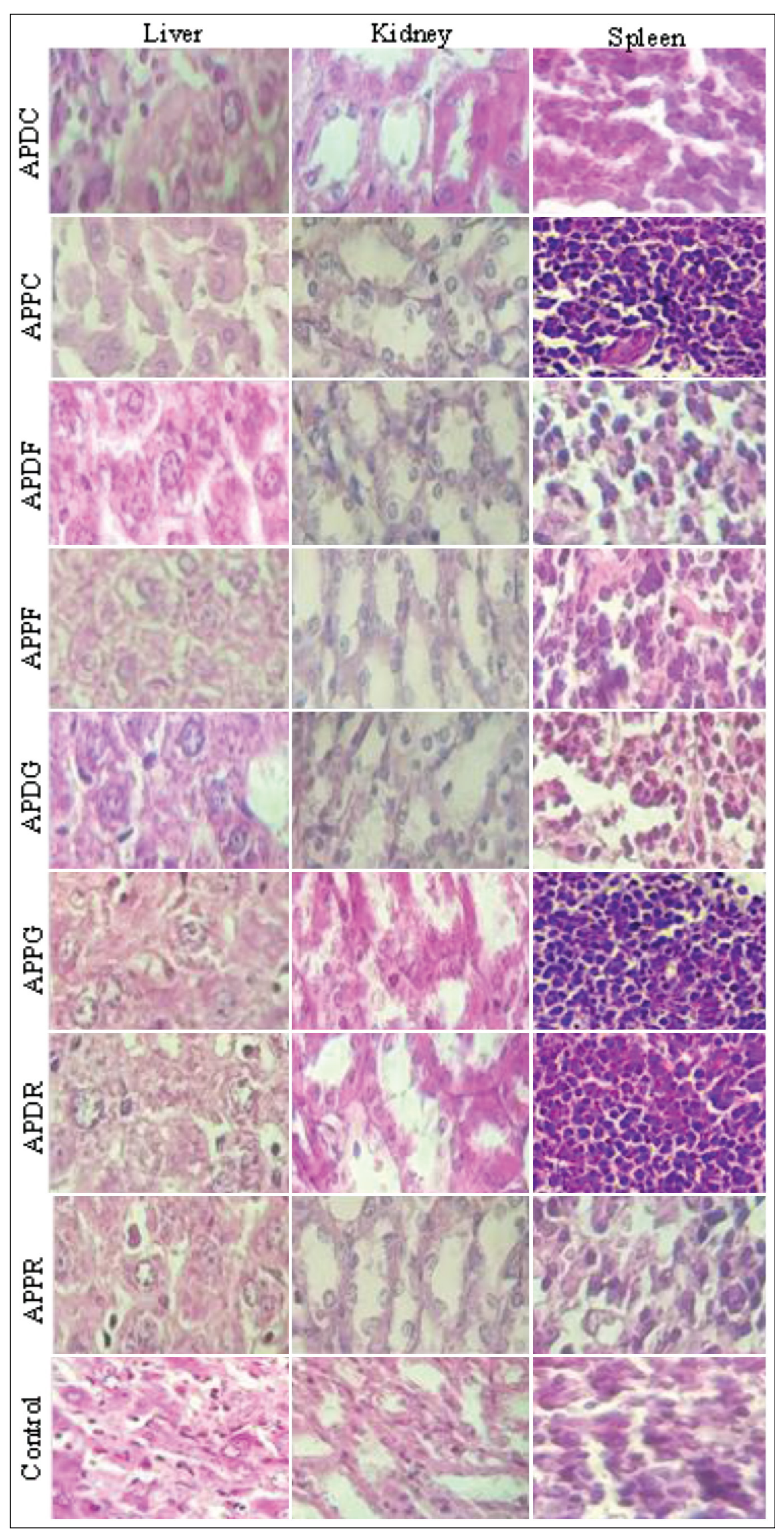

Figure-4: Histopathological observation of mice organs (liver, kidney, and spleen) from the control and the groups treated with $2000 \mathrm{mg} / \mathrm{Kg}$ of the extracts from the different parts of the two varieties Anacyclus pyrethrum var. pyrethrum (L) and Anacyclus pyrethrum var. depressus (Ball) Maire.

is explained by the fact that the plant has sedative and anesthetic effects [23]. The administration of the extracts of these two plants did not cause death in the mice. It can be deduced from this finding that the $\mathrm{LD}_{50}$ 
Table-4: Histopathological observation of mice organs (liver, kidney, and spleen) from the groups treated with 300, 500, and $2000 \mathrm{mg} / \mathrm{Kg}$ of the extracts from the different parts of the two varieties Anacyclus pyrethrum var. pyrethrum (L) and Anacyclus pyrethrum var. depressus (Ball). Maire.

\begin{tabular}{|c|c|c|c|c|c|}
\hline & \multirow[t]{2}{*}{ Samples code } & \multirow[t]{2}{*}{ Doses mg/kg } & \multicolumn{3}{|c|}{ Organs } \\
\hline & & & liver & kidneys & spleen \\
\hline Anacyclus Pyrethrum & Roots (APPR) & 300 & - & - & - \\
\hline \multirow{11}{*}{ var. Pyrethrum } & & 500 & - & - & - \\
\hline & & 2000 & - & $\begin{array}{l}\text { Focal tubular } \\
\text { necrosis }\end{array}$ & - \\
\hline & Seeds (APPG) & 300 & - & - & - \\
\hline & & 500 & - & - & - \\
\hline & & 2000 & $\begin{array}{l}\text { Hepatocyte } \\
\text { suffering }\end{array}$ & $\begin{array}{l}\text { Focal tubular } \\
\text { necrosis }\end{array}$ & Lymphoid hyperplasia \\
\hline & Leaves (AwPPF) & 300 & - & - & - \\
\hline & & 500 & $\begin{array}{l}\text { Hepatocyte } \\
\text { suffering }\end{array}$ & - & - \\
\hline & & 2000 & $\begin{array}{l}\text { Hepatocyte } \\
\text { suffering }\end{array}$ & $\begin{array}{l}\text { Focal tubular } \\
\text { necrosis }\end{array}$ & $\begin{array}{l}\text { Vascular congestion } \\
\text { Lymphoid hyperplasia }\end{array}$ \\
\hline & Capitulas (APPC) & 300 & - & - & - \\
\hline & & 500 & $\begin{array}{l}\text { Sinusoid } \\
\text { Dilatation }\end{array}$ & - & - \\
\hline & & 2000 & $\begin{array}{l}\text { Sinusoid } \\
\text { Dilatation }\end{array}$ & $\begin{array}{l}\text { Focal tubular } \\
\text { necrosis }\end{array}$ & Lymphoid hyperplasia \\
\hline Anacyclus Pyrethrum & Roots (APDR) & 300 & - & - & - \\
\hline \multirow{11}{*}{ var. Depressus } & & 500 & - & - & - \\
\hline & & 2000 & $\begin{array}{l}\text { Inflammatory } \\
\text { infiltration }\end{array}$ & - & Vascular congestion \\
\hline & Seeds (APDG) & 300 & - & - & - \\
\hline & & 500 & - & - & - \\
\hline & & 2000 & $\begin{array}{l}\text { Hepatocyte } \\
\text { suffering }\end{array}$ & - & Lymphoid hyperplasia \\
\hline & Leaves (APDF) & 300 & - & - & - \\
\hline & & 500 & $\begin{array}{l}\text { Hepatocyte } \\
\text { suffering }\end{array}$ & - & - \\
\hline & & 2000 & $\begin{array}{l}\text { Hepatocyte } \\
\text { suffering }\end{array}$ & - & $\begin{array}{l}\text { Vascular congestion } \\
\text { Lymphoid hyperplasia }\end{array}$ \\
\hline & Capitulas (APDC) & 300 & - & - & - \\
\hline & & 500 & - & - & - \\
\hline & & 2000 & $\begin{array}{l}\text { Glycogenic } \\
\text { nuclei }\end{array}$ & - & $\begin{array}{l}\text { Lymphoid hyperplasia } \\
\text { Vascular congestion }\end{array}$ \\
\hline
\end{tabular}

$\mathrm{APPR}=$ Anacyclus pyrethrum var. pyrethrum roots, $\mathrm{APPG}=$ Anacyclus pyrethrum var. pyrethrum seeds, $\mathrm{APPF}=$ Anacyclus pyrethrum var. pyrethrum leaves, APPC=Anacyclus pyrethrum var. pyrethrum capitula, APDR=Anacyclus pyrethrum var. depressus roots, APDG=Anacyclus pyrethrum var. depressus seeds, APDF=Anacyclus pyrethrum var. depressus leaves, APDC=Anacyclus pyrethrum var. depressus capitula

of the extracts of the different parts of the two plant species is $>2000 \mathrm{mg} / \mathrm{kg}$, and these results are in agreement with other studies $[37,38]$.

The root extracts of both plant at a dose of $300 \mathrm{mg} / \mathrm{kg}$ induced a significant increase of AST levels but no significant variation of ALT levels. Serum ALT and AST levels can highlight structural damage in the liver and help in the diagnosis of liver disease [39]. They have high diagnostic value in hepatology. A high concentration of AST in serum indicates lesions in different parts of the body, but ALT is more specific for liver damage, specifically explaining liver dysfunction [40]. Regarding the effect of these extracts on liver function, transaminase levels (ALT and AST) were determined. Therefore, it can be concluded that the extracts that increased AST levels could be poisoning different parts of the body. However, the roots of $A$. pyrethrum var. depressus were hepatotoxic because they significantly increased the levels of both transaminases (ALT and AST). The administration of root, seed, and capitulum extracts of both plants at a dose of $500 \mathrm{mg} / \mathrm{kg}$ induced a significant increase in AST levels but no significant changes in the other biochemical parameters. However, all plants extracts excluding the $A$. pyrethrum var. pyrethrum capitulum extract at a dose of $2000 \mathrm{mg} / \mathrm{kg}$ provoked a significant increase in AST levels. Therefore, these extracts caused damage in different parts of the body. Moreover, creatinine and urea are considered the most important markers of renal functions [41]. They are products eliminated naturally by the kidneys, and high serum levels of these compounds represent an indication or sign of deterioration of kidney function [42]. From these results, we conclude that these extracts do not induce nephrotoxicity as long as they do not cause changes in the levels of renal biomarkers (urea and creatinine). Histopathological analysis of animal organs provides the basis for evaluating the safety of treatment [43]. The results of the histological examination of the liver, kidneys, 
and spleen revealed no abnormalities in these organs associated with the administration of the various extracts the low doses. However, the groups of mice treated at a high dose $(2000 \mathrm{mg} / \mathrm{kg})$ exhibited histopathological changes in the liver, kidneys, and spleen characterized by hepatic distress, inflammatory infiltration, focal tubular necrosis, vascular congestion, and lymphoid hyperplasia. These abnormalities in these vital organs could be attributable to the presence of high concentrations of alkaloids in the administered extracts [44].

\section{Conclusion}

In the present work, the acute oral toxicity of the hydroethanolic extracts of different parts of two varieties of $A$. pyrethrum (L.) was examined in mice. The results for acute toxicity illustrated that extracts of all parts of both plants exerted some toxic effects in mice at a high dose $(2000 \mathrm{mg} / \mathrm{kg})$ as indicated by serum biochemical and/or histological analyses. However, subacute and chronic toxicity studies are required to evaluate the safe use of these plants in the long term.

It is important to note that this is the first study to provide data on the acute toxicity of extracts of different parts of A. pyrethrum var. pyrethrum (L) and A. pyrethrum var. depressus (Ball) Maire. This should be extremely useful for reference purposes and any future study of this herbal medicine.

\section{Data Availability}

The data used to support the findings of this study are available from the corresponding author upon request.

\section{Authors' Contributions}

$\mathrm{HI}, \mathrm{DB}$, and AB: Conceptualization and supervision. FZJ, AE, IE, AM, and HM: Methodology, laboratory experiments, and biochemical analysis. FZJ, HI, MB, and LK: Manuscript writing. HI: Review of the draft. All authors read and approved the final manuscript.

\section{Acknowledgments}

This work was supported by a grant from the University Sidi Mohamed Ben Abdallah for Laboratory Physiology-Pharmacology \& Environmental Health, Morocco (USMBA/L08FSDM). The authors would like to express their deep gratitude to all the professors and members of the doctoral research center who contributed to the improvement of this article.

\section{Competing Interests}

The authors declare that they have no competing interests.

\section{Publisher's Note}

Veterinary World remains neutral with regard to jurisdictional claims in published institutional affiliation.

\section{References}

1. Fennane, M., Ibn Tattou, M. and El Oualidi, J. (2014) Flore Pratique du Maroc. Vol. 3. Institut Scientifique, Rabat.

2. Patel, V.K., Patel, R.V., Venkatakrishna-Bhatt, H., Gopalakrishna, G. and Devasankariah, G. (1992) A clinical appraisal of Anacyclus pyrethrum root extract in dental patients. Phytother. Res., 6(3): 158-159.

3. Van Hecken, L. and Practoner, G. (2004) Literature Review on Anacyclus pyrethrum and Profile of Company Jura in Germany who Supplies the Pyrethrum Root Powder. Belgium. p28.

4. Daoudi, A., Mohamed, B., Jamal, I. and Laila, N. (2017) Antibacterial activity of aqueous extracts of Anacyclus pyrethrum (L) link and Corrigiola telephiifolia Pourr. from the middle atlas Region-Morocco. Eur. Sci. J., 13(33): 116.

5. Elazzouzi, H., Soro, A., Elhilali, F., Bentayeb, A. and Belghiti, M.A.E. (2014) Phytochemical study of Anacyclus pyrethrum (L.) of Middle Atlas (Morocco), and in vitro study of antibacterial activity of pyrethrum. Adv. Nat. Appl. Sci., 8(8): 10.

6. Naderi, N.J., Niakan, M. and Khodadadi, E. (2012) Determination of antibacterial activity of Anacyclus pyrethrum extract against some of the oral bacteria: An in vitro study. J. Dent. Shiraz Univ. Med. Sci., 13(2): 5.

7. Zaidi, S.M.A., Pathan, S.A., Singh, S. and Jamil, S. (2013) Anticonvulsant, anxiolytic and neurotoxicity profile of aqarqarha (Anacyclus pyrethrum) DC (Compositae) root ethanolic extract. Pharmacol. Amp Pharm., 4(7): 535-541.

8. Shahraki, M.R., Shahraki, S., Arab, M.R. and Shahrakipour, M. (2013) The effects of aqueous extract of Anacyclus pyrethrum on sperm count and reproductive organs in adult male rats. Zahedan J. Res. Med. Sci., 17(2): e1984.

9. Shahraki, S., Rad, J.S., Rostami, F.M., Shahraki, M.R. and Arab, M.R. (2014) Effects of aqueous root extracts of Anacyclus pyrethrum on gonadotropins and testosterone serum in adult male rats. Am. J. Phytomed. Clin. Ther., 2(6):767-772.

10. Hamimed, S. (2009) Caractérisation Chimique des Principes à Effet Antidermatophyte des Racines Anacyclus pyrethrum L. Universite Mentouri Constantine Faculte des Sciences Exactes Departement de Chimie.

11. Bendjeddou, D., Lalaoui, K. and Satta, D. (2003) Immunostimulating activity of the hot water-soluble polysaccharide extracts of Anacyclus pyrethrum, Alpinia galanga and Citrullus colocynthis. J. Ethnopharmacol., 88(2-3): 155-160.

12. Boonen, J., Sharma, V., Dixit, V., Burvenich, C. and De Spiegeleer, B. (2012) LC-MS N-alkylamide profiling of an ethanolic Anacyclus pyrethrum root extract. Plant. Med., 78(16): 1787-1795.

13. Sharma, V., Thakur, M., Chauhan, N.S. and Dixit, V.K. (2010) Immunomodulatory activity of petroleum ether extract of Anacyclus pyrethrum. Pharm. Biol., 48(11): 1247-54.

14. Sujith, K., Darwin, C.R. and Suba, V. (2011) Antioxidant activity of ethanolic root extract of Anacyclus pyrethrum. Int. Res. J. Pharm., 2(8):2109.

15. Manouze, H., Bouchatta, O., Bennis, M., Sokar, Z. and Ba-M'hamed, S. (2019) Anticonvulsive and neuroprotective effects of aqueous and methanolic extracts of Anacyclus pyrethrum root in kainic acid-induced-status epilepticus in mice. Epilepsy Res., 158: 106225.

16. Pahuja, M., Mehla, J., Reeta, K.H., Tripathi, M. and Gupta, Y.K. (2013) Effect of Anacyclus pyrethrum on pentylenetetrazole-induced kindling, spatial memory, oxidative stress and rho-kinase II expression in mice. Neurochem. Res., 38(3): 547-556.

17. Tyagi, S., Mansoori, M.H., Singh, N.K. and Shivhare, M.K. (2011) Antidiabetic effect of Anacyclus pyrethrum DC in alloxan induced diabetic rats. Eur. J. Biol. Sci., 3(4): 117-120. 
18. Usmani, A., Khushtar, M., Arif, M. and Siddiqui, M. (2016) Pharmacognostic and phytopharmacology study of Anacyclus pyrethrum: An insight. J. Appl. Pharm. Sci., 6(3): 144-150.

19. Doudach, L., Meddah, B., Alnamer, R., Chibani, F. and Cherrah, Y. (2012) In vitro antibacterial activity of the methanolic and aqueous extracts of Anacyclus pyrethrum used in Moroccan traditional medicine. Int. J. Pharm. Pharm. Sci., 4(3): 4.

20. Kushwaha, M. and Vijay, S. (2012) Plant Anacyclus pyrethrum a review.. J. Pharmacogn. Phytochem., 4(3): 164-170.

21. Benali, O., Selles, C. and Salghi, R. (2014) Inhibition of acid corrosion of mild steel by Anacyclus pyrethrum L. extracts. Res. Chem. Intermed., 40(1): 259-268.

22. Manouze, H., Bouchatta, O., Gadhi, A.C., Bennis, M., Sokar, Z. and Ba-M'hamed, S. (2017) Anti-inflammatory, antinociceptive, and antioxidant activities of methanol and aqueous extracts of Anacyclus pyrethrum roots. Front. Pharmacol., 8: 598

23. Muralikrishnan, K., Asokan, S., Priya, P.G., Ahmed, Z. and Ayyappadasan, G. (2017) Comparative evaluation of the local anesthetic activity of root extract of Anacyclus pyrethrum and its interaction at the site of injection in guinea pigs. Anesth. Essays Res., 11(2): 444.

24. Pahuja, M., Mehla, J., Reeta, K.H., Joshi, S. and Gupta, Y.K. (2012) Root extract of Anacyclus pyrethrum ameliorates seizures, seizure-induced oxidative stress and cognitive impairment in experimental animals. Epilepsy Res., 98(2-3): 157-165.

25. Sujith, K., Darwin, C.R., Sathish, and Suba, V. (2012) Memory-enhancing activity of Anacyclus pyrethrum in albino Wistar rats. Asian Pac. J. Trop. Dis., 2(4): 307-311.

26. Jawhari, F.Z., El Moussaoui, A., Bourhia, M., Imtara, H., Mechchate, H. and Es-Safi, I. (2020) Anacyclus pyrethrum (L): Chemical composition, analgesic, anti-inflammatory, and wound healing properties. Molecules, 25(22): 5469.

27. Shin, S., Yi, J.M., Kim, N.S., Park, C.S., Kim, S.H. and Bang, O.S. (2020) Aqueous extract of Forsythia viridissima fruits: Acute oral toxicity and genotoxicity studies. $J$. Ethnopharmacol., 249: 112381.

28. Humphries, C.J. (1979) A revision of the genus Anacyclus L. (Compositae: Anthemidaea). Bull. Br. Mus. Nat. Hist. (Bot.), 7(3): 83-142.

29. Ouarghidi, A., Powell, B., Martin, G.J. and Abbad, A. (2017) Traditional sustainable harvesting knowledge and distribution of a vulnerable wild medicinal root (A. pyrethrum var. pyrethrum) in Ait M'hamed Valley, Morocco. Econ. Bot., 71(1): 83-95.

30. Jawhari, F.Z., El Moussaoui, A., Bourhia, M., Imtara, H., Mechchate, H., Es-Safi, I., Ullah, R., Ezzeldin, E., Mostafa, G.A., Grafov, A., Ibenmoussa, S., Bousta, D. and Bari. A. (2020) Anacyclus pyrethrum (L): Chemical composition, analgesic, anti-inflammatory, and wound healing properties. Molecules, 25(22): 5469.
31. Amaghnouje, A., Mechchate, H., Es-Safi, I., Boukhira, S., Aliqahtani, A.S., Noman, O.M., Nasr, F.A., Conte, R., Calarco, A. and Bousta, D. (2020) Subacute assessment of the toxicity and antidepressant-like effects of Origanum majorana L. polyphenols in Swiss albino mice. Molecules, 25(23): 5653

32. Talke, H. and Schubert, G.E. (1965) Enzymatic urea determination in the blood and serum in the Warburg optical test. Klin. Wochenschr, 43: 174

33. Henry, R.J. (1964) Clinical Chemistry, Principles and Technics. Hoeber Medical, Harper-Row, New York.

34. Karmen, A., Wróblewski, F. and LaDue, J.S. (1955) Transaminase activity in human blood. J. Clin. Invest., 34(1): 126-133.

35. Slaoui, M. and Fiette, L. (2011) Histopathology procedures: From tissue sampling to histopathological evaluation. Drug Saf. Eval., 691: 69-82.

36. Kharchoufa, L., Merrouni, I.A., Yamani, A. and Elachouri, M. (2018) Profile on medicinal plants used by the people of North Eastern Morocco: Toxicity concerns. Toxicon, 154: 90-113.

37. Gautam, O.P., Verma, S. and Jain, S.K. (2011)Anticonvulsant and myorelaxation activity of Anacyclus pyrethrum DC. (Akarkara) root extract. Pharmacologyonline, 1(1): 121-125.

38. Kumar, V.K. and Lalitha, K.G. (2013) Acute oral toxicity studies of Anacyclus pyrethrum DC root in albino rats. $J$. Pharm. Pharm. Sci., 5(4): 675-678.

39. Traesel, G.K., de Souza, J.C., de Barros, A.L., Souza, M.A., Schmitz, W.O., Muzzi, R.M., Oesterreich, S.A. and Arena, A.C. (2014) Acute and subacute (28 days) oral toxicity assessment of the oil extracted from Acrocomia aculeata pulp in rats. Food Chem. Toxicol., 74: 320-325.

40. Utoh-Nedosa, A.U., Akah, P.A., Okoye, T.C. and Okoli, C.O. (2009) Evaluation of the toxic effects of dihydroartemisinin on the vital organs of Wistar Albino rats. Am. J. Pharmacol. Toxicol., 4(4): 169-173.

41. Palani, S., Raja, S., Kumar, R.P., Jayakumar, S. and Kumar, B.S. (2009) Therapeutic efficacy of Pimpinella tirupatiensis (Apiaceae) on acetaminophen induced nephrotoxicity and oxidative stress in male albino rats. Int. $J$. Pharm.Tech. Res., 1(3): 974-4304.

42. Ezeja, M.I., Anaga, A.O. and Asuzu, I.U. (2014) Acute and sub-chronic toxicity profile of methanol leaf extract of Gouania longipetala in rats. J. Ethnopharmacol., 151(3): 1155-1164.

43. Prabu, P.C., Panchapakesan, S. and Raj, C.D. (2013) Acute and sub-acute oral toxicity assessment of the hydroalcoholic extract of Withania somnifera roots in Wistar rats. Phytother. Res., 27(8): 1169-1178.

44. Sharma, V., Boonen, J., Spiegeleer, B.D. and Dixit, V.K. (2013) Androgenic and spermatogenic activity of alkylamide-rich ethanol solution extract of Anacyclus pyrethrum DC. Phytother. Res., 27(1): 99-106. 